\title{
Electoral reform in Europe since 1945
}

Article

Supplemental Material

online supplement

Renwick, A. (2011) Electoral reform in Europe since 1945. West European Politics, 34 (3). pp. 456-477. ISSN 1743-9655 doi: https://doi.org/10.1080/01402382.2011.555975 Available at https://centaur.reading.ac.uk/21318/

It is advisable to refer to the publisher's version if you intend to cite from the work. See Guidance on citing.

Published version at: http://www.tandfonline.com/doi/abs/10.1080/01402382.2011.555975

To link to this article DOI: http://dx.doi.org/10.1080/01402382.2011.555975

Publisher: Routledge

All outputs in CentAUR are protected by Intellectual Property Rights law, including copyright law. Copyright and IPR is retained by the creators or other copyright holders. Terms and conditions for use of this material are defined in the End User Agreement.

\section{www.reading.ac.uk/centaur}

\section{CentAUR}

Central Archive at the University of Reading

Reading's research outputs online 


\title{
Electoral System Change in Europe since 1945
}

\author{
West European Politics 34:?, ??-??
}

\section{Online Supplement:}

\section{Details of Categorizations Used in and Sources Used For Tables}

This supplement provides additional details regarding the criteria for including and classifying cases of electoral system change and lists the principal sources used for each country.

\section{Contents}

Abbreviations $\quad 2$

Criteria Used to Identify and Classify Cases 3

Sources Used to Identify and Classify Cases 16 


\section{Abbreviations}

MMM mixed-member majoritarian

MMP mixed-member proportional

PR proportional representation

SMP single-member plurality

STV single transferable vote 


\section{Criteria Used to Identify and Categorize Cases}

\section{Countries Included}

The sample used for this article includes European countries since 1945. Only independent countries that had, as of December 2009, achieved consolidated democracy are included. Membership of the European Union is taken as an indicator that democracy in a country is widely viewed as consolidated, but I also include three further cases in Western Europe that have clearly had consolidated democracy throughout the period studied: Iceland, Norway, and Switzerland. Only the most recent democratization episode is included, excluding, therefore, the short democratic interludes in some East European countries immediately after 1945 and attempts at democratization in Greece before 1974.

Eleven of the countries (Belgium, Denmark, Finland, Iceland, Ireland, Luxembourg, the Netherlands, Norway, Sweden, Switzerland, and the United Kingdom) were already democratic at the start of the period (periods of foreign occupation during the Second World War are not counted as breaks in democracy). Four (Austria, France, West Germany, and Italy) democratized in the years immediately following the start of the period (France is included in this category because it underwent a process of democratic refoundation). Malta enters the sample upon independence in 1964. Four countries (Cyprus, Greece, Portugal, and Spain) experienced transition during the 1970s (as explained in the text, Cyprus is included only from 1970). Among the countries of Eastern Europe, four (Bulgaria, Czechoslovakia, Hungary, Romania) held their first democratic and independent legislative elections in 1990, Poland followed suit in 1991, 
Estonia, Lithuania, and Slovenia did so in 1992, and Latvia completed the set in 1993. Finally, the Czech Republic and Slovakia are included from their split in 1993.

\section{Political System}

The year of transition is defined as the year of the first democratic elections during the democratization episode. (In the case of Hungary, the electoral system used for those elections was enacted in the previous calendar year, and I therefore allow for a two-year transition.) The year of transition is thus:

- before 1945: Belgium, Denmark, Finland, Iceland, Ireland, Luxembourg, the Netherlands, Norway, Sweden, Switzerland, and the United Kingdom

- 1945: Austria, France

- 1946: Italy

- 1949: Germany

- 1958: France

- 1970: Cyprus

- 1974: Greece

- 1975: Portugal

- 1977: Spain

- 1989-90: Hungary

- 1990: Bulgaria, Czechoslovakia, the Czech Republic, Slovakia, and Romania

- 1991: Poland

- 1992: Estonia, Lithuania, and Slovenia

- 1993: Latvia 
The ten years following the transition year are counted as the " 1 st decade" of the democracy and the next ten years as the "2nd decade" (in some cases these are amalgamated into the category of "new" democracy). All subsequent years count as "old" democracy.

\section{Electoral System Changes Included}

The criteria used for deciding which electoral system changes to include and which to exclude are based on Lijphart's widely recognized criteria for significance. These are:

- any change in the electoral formula (in multi-tier systems, only changes in the decisive tier);

- any change of at least 20 per cent in average district magnitude (in multi-tier systems, only changes in the upper tier);

- any change of at least 20 per cent in the national legal threshold, "or the adoption of such a threshold where none existed before";

- any change of at least 20 per cent in assembly size (Lijphart 1994: 13).

Lijphart later elaborates on what he means by the "decisive tier" in multi-tier systems: in systems with allocation of remainders at the upper tier, the lower-tier formula does count as significant; in systems with adjustment seats at the national tier, the lower-tier formula is not significant (Lijphart 1994: 32-6); in the non-compensatory multi-tier system used in past Greek elections, all tiers are significant (Lijphart 1994: 42-5).

I supplement Lijphart's criteria in two ways. First, with respect to the proportionality of the electoral system, his criteria do not entirely determine which cases should be included. I make the following additions: 
- Several countries in Eastern Europe use differentiated thresholds, where different thresholds apply to parties running independently and coalitions of parties running jointly. Lijphart did not encounter such thresholds in his case set. I err here on the side of inclusion, allowing changes of at least 20 per cent in any one of a ladder of differentiated thresholds to count as significant.

- Lijphart's rules cover systems of multi-tier districting (including MMP), but they do not tell us how to deal with mixed-independent systems (Massicotte and Blais 1999). The issue with such systems is what proportion of seats need to be affected by a change for it to be considered significant. Lijphart rightly ignores the abolition of the STV system that, before 1948, was used to elect 1.4 per cent of the seats in the UK House of Commons: the UK system had not been mixed in any serious sense. But how many seats must be involved before a system becomes mixed? We could apply the 20 per cent rule to this question. But this would exclude, for example, the reform in Bulgaria in 2009, which replaced a pure list PR system with a system in which just fewer than 13 per cent of the seats are elected by SMP. To exclude such a change while including adjustments in PR formulas that shift only a handful of seats would be perverse. We need a lower threshold here than for the other criteria that Lijphart considers. I therefore follow Massicotte and Blais (1999: 345) and say that, in mixed-independent systems, a change in electoral system type affecting at least 5 per cent of the seats should count as significant. 
My second extension of Lijphart's criteria is the inclusion of changes that may leave proportionality unaltered but that affect personalization. I define personalization as the degree to which the electoral system focuses voters' attention and choices upon political parties or upon individual candidates. Drawing on existing literature (e.g., Carey and Shugart 1995; Karvonen 2004, 2010; André et al. 2009), I identify four aspects of electoral systems that influence personalization:

- preference voting: opportunities to express preferences across individual candidates within a party;

- seat allocation: the weight given to these preference votes in determining which candidates are elected;

- vote pooling: whether a vote for a particular candidate can help a party's other candidates secure election;

- district magnitude: the number of seats available in a district.

For two of these aspects, their relationship to personalization is unambiguous. First, regarding seat allocation, the greater the weight attached to preference votes in determining who is elected, the greater is the personalization of the election. It is common to distinguish between closed list systems, semi-open list systems, and fully open list systems. In the first case, voters have no say over the order in which a party's candidates are elected, while in the last, voters entirely determine that order. In the case of semi-open list systems, preference votes can influence the order, but parties' prior orderings matter too. Thus, any shift from closed lists to semi-open lists or from semiopen lists to fully open lists constitutes an increase in personalization. In addition, we 
must allow for variation among semi-open list systems: these vary widely from systems in which it is very difficult and rare for voters to change list order to those in which party orderings exist but are frequently subverted. Semi-open list systems in Europe fall into two categories: in some, a candidate must secure in preference votes a certain percentage of the party's total vote in order to rise to the top of the list; in others, votes cast for a party list without expression of preferences are counted as votes for the ordering decided by the party and are counted alongside preference votes when determining each candidate's level of support. In analogy to Lijphart's approach, I count as significant any shift between categories (closed list, semi-open list, and open list) and, among semi-open systems, any change of at least 20 per cent in the thresholds required before preference votes change list order or in the weight attached to non-preference votes.

Second, the greater is vote pooling, the weaker is the personalization of the electoral system. Thus, systems with pooling (list systems, whether proportional or majoritarian and whether open or closed) are, other things being equal, less personalized than non-list systems. (Perplexingly, Carey and Shugart [1995: 421] see pooling as occurring in single-member-plurality systems and in single transferable vote, but I follow [Karvonen 2004: 207] in categorizing these as systems without pooling.) Pooling can also occur below the level of a party's whole list, thereby allowing candidates to rise up the list on the basis of another candidate's popularity. Such was the case in Finland before 1954. Like pooling at the level of the party, intra-party pooling reduces personalization.

The remaining two aspects of personalization are more problematic. The difficulties associated with district magnitude are well known: as Carey and Shugart 
(1995: 430-432) argue, the value of candidates' personal reputations falls as district magnitude rises in closed list systems, but it may rise in open list systems. The same is likely to apply to the idea of personalization employed here, which focuses on the voters' perspective. Given, however, that there is a continuum between entirely closed and fully open lists, we need to ask at what point on that continuum personalization stops falling as district magnitude grows and where it starts to rise. This is no straightforward matter.

Preference voting is also somewhat ambiguous. Clearly, personalization is greater where voters can express intra-party preferences than where they cannot. The candidate-centric literature adds that the value of personal reputations is at its greatest when voters can express a preference for just one candidate and somewhat lower when they can vote for multiple candidates. This makes sense from the candidate perspective. From voters' perspective, however, it seems at least as plausible that they would see multiple preference votes as allowing them to express their views on candidates more fully than a single preference vote.

Further conceptual work is required to disentangle these complexities, and this broad survey article is not the place to do that. I therefore operationalize a limited view of personalization, taking account only of changes in seat allocation and vote pooling as described above. By including the difference between closed and semi-open or open lists under the heading of seat allocation, I necessarily capture any change in whether voters can cast intra-party preference votes, but I do not take account of the number of preference votes. Nor do I allow for district magnitude, though shifts between singleand multi-member districts will often count as significant because they affect seat allocation and/or vote pooling. 


\section{Changes in Proportionality}

Table 1 in the article shows the direction of reform in cases where there was a preexisting democratic electoral system. Where there was no such system, it shows the nature of the new system adopted. In the cases of countries gaining independence (the Baltic states, the Czech Republic, Slovakia, and Slovenia, and Malta), I include comparison with previous democratic elections for republic-wide (in the Maltese case, dependency-wide) legislative bodies. (Cyprus, however, had no island-wide legislative elections before 1960.)

In respect of new adoptions, I classify systems into three categories: proportional, intermediate ("mid"), and majoritarian. Proportional systems include list PR, STV, and MMP systems. Majoritarian systems include SMP, block vote, and two-round systems. In the intermediate category I include MMM, bonus-adjusted systems, and the Greek system of "reinforced PR".

The classification of the direction of change in cases where there was a preexisting democratic system requires further elaboration. Proportionality is usefully thought of as comprising two elements: the height of the threshold that a party must pass in order to enter the legislature; and the degree to which seats are distributed in proportion to votes among the parties passing this threshold. Any electoral system change that counts as significant in terms of proportionality by the criteria above and that either reduces the threshold of inclusion or increases proportionality among included parties without causing an opposite effect on the other dimension clearly increases proportionality. Thus, increases in assembly size or district magnitude or reductions in legal thresholds all increase proportionality. In order to establish the direction of change 
in proportionality implied by a change in electoral formula, I employ the ranking of proportional electoral formulas offered in Gallagher and Mitchell (2005: 589). Thus, among the systems encountered in this case set, the most proportional systems are those employing either the Hare quota with largest remainders or the pure Sainte-Laguë method; modified Sainte-Laguë comes next, followed by the Droop quota with largest remainders, followed by d'Hondt, followed by the Imperiali quota with largest remainders.

Problems arise when a package of reforms has mixed effects. In some such cases, the overall effect is clear. In others, it is not, and I describe their effects on proportionality as "mixed". The following complex cases may be noted:

- The reform enacted in Austria in 1992 changed the district structure and introduced a new threshold. According to Müller (2005: 400), it "was meant to strengthen the accountability of MPs while maintaining roughly the current level of proportionality". I therefore classify it as having mixed effect.

- The Bulgarian reform of 1991 replaced the MMM system used in 1990, which comprised 200 seats elected by PR and 200 elected by SMP, with a pure PR system electing 240 seats. The change increased proportionality by removing the large majoritarian component, but also reduced it by sharply reducing assembly size. The overall effect was, however, to increase proportionality.

- The Danish reform of 1953 introduced a variety of changes, but the most important all restricted the upper compensatory tier, thereby reducing proportionality (cf. Elklit 2002: 43-6). 
- The German reforms of 1953 and 1956 both had mixed effects. The first raised the 5 per cent threshold from the Land to the national level but also allowed voters two votes rather than one. The second raised the alternative threshold from one district seat to three, but also allowed parties to pool remainder votes nationally.

- Lijphart (1994: 45) suggests that the Greek reform of 1985 increased proportionality by eliminating a 17 per cent threshold. But Clogg (1987: 200) points out that this change had the effect of reducing the number of seats allocated at the second tier of distribution and increasing the number allocated at the third tier, which was markedly disproportional. Overall, the reform lowered the threshold of inclusion for small parties but also increased the seat bonus of the largest party (Clogg 1987: 199). I therefore classify it as mixed.

- The Greek reform of 2004 replaced Greece's traditional multi-tier "reinforced PR" system with a bonus-adjusted system. Given that the reinforced PR system was often treated as a form of PR, this change might appear to have reduced proportionality. But the disproportionality of reinforced PR was so great that the change in fact increased proportionality (e.g., Patrikios and Karyotis 2008: 357).

- The reform in Iceland in 2000 introduced a number of conflicting changes. Hardarson (2002: 151) implies that these were designed to compensate each other, such as to leave proportionality unchanged. I therefore count this as a mixed case.

- The Italian reform of 2005 increased proportionality among the parties of the winning coalition and among all other parties, but it introduced the possibility of significant disproportionality between the winning coalition and all other parties 
by guaranteeing a majority for the largest coalition. I therefore categorize it as mixed.

- The reform in Slovenia in 2000 introduced several changes, but the most important was an increase in the threshold from around 3.2 per cent to 4 per cent. I therefore treat it as having reduced proportionality.

- The Swedish reform of 1969 both raised the threshold of inclusion (by creating a 4 per cent national threshold) and increased proportionality among included parties (by introducing an upper tier of distribution). I treat it as mixed.

Finally, where a reform is not significant in terms of proportionality, I describe proportionality as "unchanged".

\section{Changes in Personalization}

As in the case of proportionality, Table 1 shows how each reform affected personalization where there was a pre-existing democratic electoral system; where there was no such system, it shows the level of personalization in the system adopted.

In respect of new adoptions, I allow three categories: personalized, intermediate ("mid"), and non-personalized. The first of these includes open list systems and non-list systems (such as STV and SMP), the second includes mixed systems (MMP and MMM)

and systems with semi-open lists or mixtures of closed and open lists, while the third includes closed-list systems.

As outlined above, I count only two sorts of change as constituting significant changes in personalization: changes in the weight of preference votes in determining the order in which a party's candidates are elected; and changes in whether there is vote 
pooling at the party or sub-party level. Any increase in the weight of preference votes or reduction in vote pooling that counts as significant by the criteria above increases personalization. I categorize only one reform as having had mixed effects. This was the Italian reform of 1993, which replaced open-list PR with semi-compensatory MMM. This change eliminated pooling for the 75 per cent of seats that were to be elected in single-member districts, but also replaced open lists with closed lists for the remaining 25 per cent of seats that continued to be elected through PR. (A reform passed in 1991, which does not count as significant in terms of the criteria used here, had already cut the number of preference votes that voters could cast.) Many reforms, finally, leave personalization unchanged.

A note is required on the Estonian reforms of 1994 and 2002. The second of these is clearly significant: it introduced an element of list openness at the national allocation tier, where previously lists had been entirely closed. The 1994 is more marginal: it involved a relatively small change at district level. Its effect was, however, to limit vote pooling only to those candidates with significant personal following, and I therefore include it as a significant increase in personalization.

\section{Categorization of Reform Processes}

Where possible, I place each case of reform within the types of electoral reform process defined in the text of the article. This is done largely on the basis of the existing secondary literature, though in some cases I draw also upon primary sources and contemporaneous newspaper reporting. Clearly, such categorizations are open to interpretation and debate. Indeed, there is significant disagreement in the literature on some cases, such as the introduction of MMP in West Germany in 1949 and the reforms 
in Poland in the early 1990s, as to the processes that underlay them. In such cases, I seek in my categorization to reflect the balance of debate. In most cases, however, such sharp disagreements do not arise.

As the text of the article indicates, some of the categories of reform process identify pure types that are unlikely to exist in undiluted form in practice. Table 1 categorizes cases according to the type that fits them most closely, but in some cases also indicates that they show elements of one or more other types. Subsequent tables categorize cases according to the single dominant type (the first category mentioned in Table 1). The one exception is that Table 2 continues to allow for cases that appear to mix aspects of elite settlement and elite bargain (or where the degree of settlement versus bargain is impossible to identify from the sources available).

There are nine cases where I have been unable to find sources that allow the reform process to be classified. I would welcome suggestions on these. Indeed, as I have emphasized, I acknowledge that some of the categorizations shown may miss key aspects of particular reform episodes. I hope that country specialists will feel free to contest the categorizations that I have provided. 


\section{Sources Used to Identify and Categorize Cases}

Several broad surveys of electoral system changes already exist, but none is adequate for the tasks pursued here. The most detailed and comprehensive is Matt Golder's database of electoral systems (Golder 2004, 2005), but this makes no mention of legal thresholds or list openness and ends in 2000. Lijphart (1994) covers changes in proportionality but not in personalization, and is now twenty years old. Colomer (2004: 74-6) provides a survey of changes, but gives little detail. Likewise, the International Institute for Democracy and Electoral Assistance (IDEA) provides a broad overview of systems currently in force, but does not detail within-type reforms (IDEA n.d.; Reynolds, Reilly, and Ellis 2005: 166-73). The Inter-Parliamentary Union's Parline Database contains much useful material, but is not systematic and often does not provide all necessary details (IPU n.d.). Johnson and Wallack's Database of Electoral Systems and the Personal Vote (2007) focuses directly on aspects of the electoral system relating to personalization, but relies on the problematic IPU database and does not give detail on, for example, degrees of list openness. Furthermore, none of these sources gives any evidence on processes of reform.

While drawing on these general sources, the survey in Table 1 of the article therefore supplements them with further sources on particular cases. These are listed below.

\section{General Sources and Sources for This Supplement}

André, Audrey, Sam Depauw, and Kris Deschouwer (2009). "District Magnitude and Legislators' Personal Vote-Seeking". APSA Annual Meeting, Toronto. 
Carey, John M., and Matthew Soberg Shugart (1995). "Incentives to Cultivate a Personal Vote: A Rank Ordering of Electoral Formulas”, Electoral Studies, 14:4, 417-39.

Colomer, Josep M. (2004). “The Strategy and History of Electoral System Choice”, in Josep M. Colomer (ed.), Handbook of Electoral System Choice. Basingstoke: P Palgrave Macmillan, 3-78.

Gallagher, Michael, and Paul Mitchell, eds. (2005). The Politics of Electoral Systems. Oxford: Oxford University Press.

Golder, Matt (2004). "Democratic Electoral Systems around the World, 1946-2000" (dataset and codebook). Accessed at http://homepages.nyu.edu/ mrg217/elections.html, 15 February 2009.

Golder, Matt (2005). "Democratic Electoral Systems around the World, 1946-2000”, Electoral Studies, 24:1, 103-121.

IDEA (n.d.). "Table of Electoral Systems Worldwide". Accessed at http://www.idea.int/esd/world.cfm, 29 December 2009.

IPU (n.d.). "Inter-Parliamentary Union Parline Database on National Parliaments". Accessed at http://www.ipu.org/parline-e/parlinesearch.asp, 29 December 2009.

Johnson, Joel W., and Jessica S. Wallack (2007). Database of Electoral Systems and the Personal Vote. Accessed at http://dss.ucsd.edu/ jwjohnso/espv.htm, 2 April 2010.

Karvonen, Lauri (2004). "Preferential Voting: Incidence and Effects", International Political Science Review, 25:2, 203-26.

Karvonen, Lauri (2010). The Personalisation of Politics: A Study of Parliamentary Democracies. Colchester: ECPR Press. 
Lijphart, Arend (1994). Electoral Systems and Party Systems: A Study of Twenty-Seven Democracies, 1945-1990. Oxford: Oxford University Press.

Massicotte, Louis, and André Blais (1999). "Mixed Electoral Systems: A Conceptual and Empirical Survey", Electoral Studies, 18:3, 341-66.

Reynolds, Andrew, Ben Reilly, and Andrew Ellis (2005). Electoral System Design: The New International IDEA Handbook. Stockholm: International Institute for Democracy and Electoral Assistance.

\section{Country Sources}

Austria

Barker, Elisabeth (1973). Austria 1918-1972. London: Macmillan.

Carstairs, Andrew McLaren (1980). A Short History of Electoral Systems in Western Europe. London: George Allen \& Unwin.

Hiscocks, Richard (1953). The Rebirth of Austria. London: Oxford University Press.

Kitzinger, U. W. (1958). “The Austrian Electoral System”, Parliamentary Affairs, 12:3, $392-404$.

Knight, Robert (1996). "Narratives in Post-war Austrian Historiography", in Anthony Bushell (ed.), Austria 1945-1955: Studies in Political and Cultural Reemergence. Cardiff: University of Wales Press, 11-36.

Kohn, Walter S. G. (1971). "The Austrian Parliamentary Elections of 1971", Parliamentary Affairs, 25:2, 163-77. 
Müller, Wolfgang C. (1984). "Direktwahl und Parteiensystem”, in Andreas Khol and Alfred Stirnemann (eds.), Österreichisches Jahrbuch für Politik 1983. Munich: R. Oldenbourg.

Müller, Wolfgang C. (2003). “Austria: Imperfect Parliamentarism but Fully-Fledged Party Democracy”, in Kaare Strøm, Wolfgang C. Müller, and Torbjörn Bergman (eds), Delegation and Accountability in Parliamentary Democracies. Oxford: Oxford University Press, 221-52.

Müller, Wolfgang C. (2005). “Austria: A Complex Electoral System with Subtle Effects”, in Michael Gallagher and Paul Mitchell (eds.), The Politics of Electoral Systems. Oxford: Oxford University Press, 397-415.

Müller, Wolfgang C. (2009a). "The Snap Election in Austria, September 2008”, Electoral Studies, 28:3, 514-17.

Müller, Wolfgang C. (2009b). Personal communication.

\section{Belgium}

De Winter, Lieven (2005). “Belgium: Empowering Voters and Party Elites?”, in Michael Gallagher and Paul Mitchell (eds.), The Politics of Electoral Systems. Oxford: Oxford University Press, pp. 417-32.

Downs, William M. (1995). “The Belgian General Election of 1995”, Electoral Studies, $14: 3,336-41$.

Hooghe, Marc, Bart Maddens, and Jo Noppe (2003). "Why Parties Adapt: Electoral Reform, Party Finance, and Party Strategy in Belgium”, Electoral Studies, 25:2, $351-68$ 
Hooghe, Marc, Jo Noppe, and Bart Maddens (2003). “The Effect of Electoral Reform on the Belgian Election Results of 18 May 2003”, Representation, 39:4, 270-76.

Pilet, Jean-Benoit (2007). Changer pour gagner? Les réformes des lois électorales en Belgique. Brussels: Edition de l’Université de Bruxelles.

Pilet, Jean-Benoit (2009). Personal communication.

\section{Bulgaria}

Birch, Sarah, Frances Millard, Marina Popescu, and Kieran Williams (2002). Embodying Democracy: Electoral System Design in Post-Communist Europe. Basingstoke: Palgrave Macmillan, 109-27.

Crampton, Richard J. (1995). “The Bulgarian Elections of December 1994”, Electoral Studies, 14:2, 236-40.

Crampton, Richard (1997). “The Bulgarian Elections of 19 April 1997”, Electoral Studies, 16:4, 560-63.

Hanley, Sean. “Dr Sean's Diary” (blog). Accessed at http://drseansdiary.blogspot.com/.

Harper, M. A. G. (2003). "The 2001 Parliamentary and Presidential Elections in Bulgaria”, Electoral Studies, 22:2, 335-44.

Sophia Echo. Available at sofiaecho.com.

Sophia News Agency. Available at www.novinite.com.

SETimes. Available at www.setimes.com.

Spirova, Maria (2006). "The Parliamentary Elections in Bulgaria, June 2005", Electoral Studies, 25:3, 616-21.

Spirova, Maria (2009). Personal communication. 
Spirova, Maria (2010). "The 2009 Parliamentary Elections in Bulgaria”, Electoral Studies 29:?, ??-??.

Cyprus

Christophorou. Christophoros (n.d.). "Eklektor" (website). Available at www.eklektor.org.

Christophorou, Christophoros (2001). "Consolidation and Continuity through Change: Parliamentary Elections in Cyprus, May 2001”, South European Society and Politics, 6:2, 97-118.

Christophorou, Christophoros (2006). "Party Change and Development in Cyprus (1995-2005)", South European Society and Politics, 11:3-4, 513-42.

Christophorou, Christophoros (2007). "An Old Cleavage Causes New Divisions: Parliamentary Elections in the Republic of Cyprus, 21 May 2006”, South European Society and Politics, 12:1, 111-28.

Christophorou, Christophoros (2009a). “The Evolution of Greek Cypriot Party Politics”, in James Ker-Lindsay and Hubert Faustmann (eds.), The Government and Politics of Cyprus. Bern: Peter Lang.

Christophorou, Christophoros (2009b). Personal communication.

Parliament of the Republic of Cyprus (n.d.). "Historical Overview". Available at http://www.parliament.cy/parliamentENG/index.htm.

Sofroniou, Sofronis (1995). “Change the Electoral System”, Cyprus Mail, 18 January.

Wilder, Paul (1991). “And What Do They Do in the Other Half of Cyprus?”, Representation, 30:109 (spring), 14-15. 


\section{Czechoslovakia}

Birch, Sarah, Frances Millard, Marina Popescu, and Kieran Williams (2002). Embodying Democracy: Electoral System Design in Post-Communist Europe. Basingstoke: Palgrave Macmillan, 67-75.

Elster, Jon (1995). "Transition, Constitution-Making and Separation in Czechoslovakia", Archives Européenes de Sociologie, 36:1, 105-34.

Havel, Václav (1992 [1990]). “New Year's Address”, in Václav Havel, Open Letters: Selected Writings 1965-1990, ed. Paul Wilson. New York: Vintage, 390-96.

Jičínský, Zdeněk (1993). Československý parlament v polistopadovém vývoji. Prague: NADAS-AFGH.

Kopecký, Petr (2001a). Parliaments in the Czech and Slovak Republics: Party Competition and Parliamentary Institutionalization. Aldershot: Ashgate.

Kopecký, Petr (2001b). "The Czech Republic: From the Burden of the Old Federal Constitution to the Constitutional Horse Trading among Political Parties", in Jan Zielonka (ed.), Democratic Consolidation in Eastern Europe, Volume 1: Institutional Engineering. Oxford; Oxford University Press, 319-46.

Kopecký, Petr (2004). “The Czech Republic: Entrenching Proportional Representation", in Josep Colomer (ed.), Handbook of Electoral System Choice. Basingstoke: Palgrave Macmillan, 347-58.

Kusin, Vladimir V. (1990). "Vaclav Havel's First Term”, RFE Report on Eastern Europe 1:29, 11-13.

Občanské fórum (1990a). “Zápis ze Sněmu Občanského fóra, 6. ledna 1990”. Mimeo. 
Občanské fórum (1990b). “Zápis ze Sněmu Koordinačního centra Občanského fóra dne 20. ledna 1990". Mimeo.

Občanské fórum (1990c). “Zápis ze Sněmu Koordinačního centra Občanského fóra dne 3.2.1990". Mimeo.

Občanské fórum (1990d). “Zápis ze Sněmu Koordinačního centra Občanského fóra dne 17.2.1990”. Mimeo.

Pehe, Jiri (1990f). “The Electoral Law”, RFE Report on Eastern Europe, 1:11, 15-18.

\section{Czech Republic}

Birch, Sarah, Frances Millard, Marina Popescu, and Kieran Williams (2002). Embodying Democracy: Electoral System Design in Post-Communist Europe. Basingstoke: Palgrave Macmillan, 79-86.

Kopecký, Petr (2001). Parliaments in the Czech and Slovak Republics: Party Competition and Parliamentary Institutionalization. Aldershot: Ashgate.

Kopecký, Petr (2004). "The Czech Republic: Entrenching Proportional Representation", in Josep Colomer (ed.), Handbook of Electoral System Choice. Basingstoke: Palgrave Macmillan, 347-58.

Parliament of the Czech Republic (1995). “Act No. 237 on Elections to the Parliament of the Czech Republic, and on Amendments to Certain Other Acts”, 27 September. Available at www.legislationline.org.

Parliament of the Czech Republic (1995). “Zákon 247/1995 Sb. o volbách do Parlamentu České Republiky a o změně a doplnění některých dalších zákonů”, incorporating amendments to 2004. Available at http://www.psp.cz/docs/texts/1995-247.html. 
Plecitá-Vlachová, Klára, and Mary Stegmaier (2007). “The Parliamentary Election in the Czech Republic, June 2006”, Electoral Studies, 27:1, 179-84.

Williams, Kieran (2005). "Judicial Review of Electoral Thresholds in Germany, Russia, and the Czech Republic", Election Law Journal, 4:3, 191-206.

Williams, Kieran (2009). Personal communication.

\section{Denmark}

Elklit, Jørgen (1993). “Simpler Than Its Reputation: The Electoral System in Denmark since 1920", Electoral Studies, 12:1, 41-57.

Elklit, Jørgen (2002). “The Politics of Electoral System Development and Change: The Danish Case", in Bernard Grofman and Arend Lijphart (eds.), The Evolution of Electoral and Party Systems in the Nordic Countries. New York: Agathon, 1566.

Elklit, Jørgen (2009). Personal communication.

Laakso, Markku, and Rein Taagepera (1978). "Proportional Representation in Scandinavia; Implications for Finland", Scandinavian Political Studies, 1:1, 4360.

Miller, Kenneth E. (1964). “The Danish Electoral System”, Parliamentary Affairs, 18:1, $71-81$.

Ministry of the Interior and Social Affairs (2009). The Parliamentary Electoral System in Denmark. Copenhagen: Ministry of the Interior and Social Affairs. Accessed at http://elections.ism.dk/parliament-elections/Documents/Parlelectsys.pdf, 24 March 2010. 
Pedersen, Mogens N. (1966). "Preferential Voting in Denmark: The Voters' Influence on the Election of Folketing Candidates", Scandinavian Political Studies, 1 (old series), $167-87$.

Togeby, Lise, Jørgen Goul Andersen, Peter Munk Christiansen, Torben Beck Jørgensen, and Signild Vallgårda (2003). Democracy and Power in Denmark: Conclusions. Aarhus: Magtudredningen.

\section{Estonia}

Grofman, Bernard, Evald Mikkel, and Rein Taagepera (1989). "Electoral System Changes in Estonia, 1989-1993", Journal of Baltic Studies, 30:3, 227-49.

Mikkel, Evald, and Vello Pettai (2004). "The Baltics: Independence with Divergent Electoral Systems", in Josep Colomer (ed.), Handbook of Electoral System Choice. Basingstoke: Palgrave Macmillan, 332-46.

Pettai, Vello (2001). "Estonia: Positive and Negative Institutional Engineering", in Jan Zielonka (ed.), Democratic Consolidation in Eastern Europe, Volume 1: Institutional Engineering. Oxford: Oxford University Press, 111-38.

Pettai, Vello (2004). "The Parliamentary Elections in Estonia, March 2003", Electoral Studies, 23:4, 828-34.

Riigikogu Election Act (1994). Available in English translation on the website of the University of Essex project on "Political Transformation and the Electoral Process in Post-Communist Europe". Accessed at http://www2.essex.ac.uk/elect/database/legislationAll.asp?country=estonia\&legisl ation=ee94\#chapter7, 24 March 2010. 
Riigikogu Election Act (2002). Accessed at http://www.legaltext.ee/text/en/X60044K2.htm, 24 March 2010.

Solvak, Mihkel, and Vello Pettai (2008). "The Parliamentary Elections in Estonia, March 2007”, Electoral Studies, 27:3, 574-77.

Taagepera, Rein (1995). “Estonian Parliamentary Elections, March 1995”, Electoral Studies, 14:3, 328-31.

Finland

Nurmi, Hannu, and Lasse Nurmi (2007), “The Parliamentary Election in Finland, March 2007”, Electoral Studies, 26:4, 797-803.

Raunio, Tapio (2004). “The Changing Finnish Democracy: Stronger Parliamentary Accountability, Coalescing Political Parties and Weaker External Constraints”, Scandinavian Political Studies, 27:2, 133-52.

Sundberg, Jan (2002). "The Electoral System of Finland: Old, and Working Well”, in Bernard Grofman and Arend Lijphart (eds.), The Evolution of Electoral and Party Systems in the Nordic Countries. New York: Agathon, 67-99.

Törnudd, Klaus (1968). The Electoral System of Finland. London: Hugh Evelyn.

France

Alexander, Gerard (2004). "France: Reform-Mongering between Majority Runoff and Proportionality", in Josep M. Colomer (ed.), Handbook of Electoral System Choice. Basingstoke: Palgrave Macmillan, 209-21. 
Browne, Eric C., and Keith E. Hamm (1996). "Legislative Politics and the Paradox of Voting: Electoral Reform in Fourth Republic France”, British Journal of Political Science, 26:2, 165-98.

Cole, Alistair, and Peter Campbell (1989). French Electoral Systems and Elections since 1789. Gower: Aldershot.

Criddle, Byron (1992). "Electoral Systems in France", Parliamentary Affairs, 45:1, 10816.

Debré, Jean-Louis (1974). Les Idées Constitutionnelles du Général de Gaulle. Paris: Librairie Générale de Droit et de Jurisprudence.

Debré, Michel (1947). La Mort de l'état républicain. Paris: Gallimard.

Debré, Michel (1981). “The Constitution of 1958, Its Raison d'être and How It Evolved", in William G. Andrews and Stanley Hoffmann (eds.), The Impact of the Fifth Republic on France. Albany, NY: State University of New York Press, 114.

De Gaulle, Charles (1959). War Memoirs, Volume 3: Salvation, 1944-1946, trans. Richard Howard. London: Weidenfeld and Nicolson.

De Gaulle, Charles (1970 [1950]). “Conférence de Presse Tenue au Palais d'Orsay, 16 mars 1950”, in Charles de Gaulle, Discours et Messages, Volume 2. Paris: Plon, $344-58$

Favier, Pierre, and Michel Martin-Roland (1991). La Décennie Mitterrand, Volume 2: Les Épreuves (1984-1988). Paris: Éditions du Seuil.

Frears, John (1977). Political Parties and Elections in the Fifth Republic. London: C. Hurst. 
Frears, John (1986). “The French Electoral System in 1986: PR by Lists and Highest Average", Parliamentary Affairs, 39:4, 489-95.

Gaxie, Daniel (1990). "Les partis politiques et les modes de scrutin en France, (19851986), croyances et intérêts", in Serge Noiret (ed.), Political Strategies and Electoral Reforms: Origins of Voting Systems in Europe in the 19th and 20th Centuries. Baden-Baden: Nomos Verlagsgesellschaft, 423-50.

Goguel, François (1952). France under the Fourth Republic. Ithaca, NY: Cornell University Press.

Goldey, David, and Philip Williams (1983). "France", in Vernon Bogdanor and David Butler (eds.), Democracy and Elections: Electoral Systems and their Political Consequences. Cambridge: Cambridge University Press, 62-83.

Knapp, Andrew (1987). “Proportional but Bipolar: France’s Electoral System in 1986”, West European Politics, 10:1, 89-114.

Knapp, Andrew (2007). “Introduction: France's 'Long' Liberation, 1944-47”, in Andrew Knapp (ed.), The Uncertain Foundation: France at the Liberation, 194447. Basingstoke: Palgrave Macmillan, 1-22.

Neumann, Robert G. (1951). "The Struggle for Electoral Reform in France”, American Political Science Review, 45:3, 741-55.

Rioux, Jean-Pierre (1987). The Fourth Republic, 1944-1958, trans. Godfrey Rogers. Cambridge: Cambridge University Press.

Shennan, Andrew (1989). Rethinking France: Plans for Renewal 1940-1946. Oxford: Clarendon Press. 
Wahl, Nicholas (1959a). “The French Constitution of 1958: II. The Initial Draft and Its Origins", American Political Science Review, 53:2, 358-82.

Wahl, Nicholas (1959b). The Fifth Republic: France's New Political System. New York: Random House.

Williams, Philip (1954). Politics in Post-War France: Parties and the Constitution in the Fourth Republic. London: Longmans, Green, and Co.

Williams, Philip M. (1964). Crisis and Compromise: Politics in the Fourth Republic. London: Longman.

Williams, Philip M., and Martin Harrison (1959). "France 1958”, in D. E. Butler, Philip M. Williams, Martin Harrison, Zbigniew Pelczynski, Basil Chubb, and R. R. Farquharson, Elections Abroad. London: Macmillan, 11-90.

Williams, Philip M., and Martin Harrison (1961). De Gaulle's Republic, 2nd edition. London: Longmans.

Wright, Gordon (1950). The Reshaping of French Democracy. London: Methuen \& Co.

\section{Germany}

Bawn, Kathleen (1993). “The Logic of Institutional Preferences: German Electoral Law as a Social Choice Outcome", American Journal of Political Science, 37:4, 96589.

Bundestag (2008). "Federal Elections Act", as amended 17 March 2008. Accessed at http://www.bundeswahlleiter.de/en/bundestagswahlen/rechtsgrundlagen/bundesw ahlgesetz.html, 24 March 2010. 
Bundestag (2010). "How Votes Are Translated into Seats". Accessed at http://www.bundestag.de/htdocs_e/bundestag/elections/arithmetic/index.html, 24 March 2010.

Bundeswahlleiter, Der (2009). "Neues Sitzzuteilungsverfahren bei Bundestagswahl und Europawahl". Accessed at http://www.bundeswahlleiter.de/de/aktuelle_mitteilungen/downloads/Kurzdarst_S itzzuteilung.pdf, 24 March 2010.

Helms, Ludger (2010). “The German Federal Election, September 2009”, Electoral Studies, 29:?, ??-??.

Kitzinger, Uwe (1957). “The West German Electoral Law”, Parliamentary Affairs, 11:2, $220-38$.

Merkl, Peter (1963). The Origin of the West German Republic. New York: Oxford University Press.

Pollock, James K. (1952). “The Electoral System of the Federal Republic of Germany: A Study in Representative Government”, American Political Science Review, 46:4, $1056-68$.

Scarrow, Susan (2001). "Germany: The Mixed-Member System as a Political Compromise", in Matthew Soberg Shugart and Martin P. Wattenberg (eds.), Mixed-Member Electoral Systems: The Best of Both Worlds? Oxford: Oxford University Press, 57-69. 
Greece

Alivizatos, Nicos, and Pavlos Eleftheriadis (2002). "The Greek Constitutional Amendments of 2001", South European Society and Politics, 7:1, 63-71.

Athens News Agency Bulletin. Available at www.hri.org.

Clogg, Richard (1983). "Greece", in Vernon Bogdanor and David Butler (eds.), Democracy and Elections: Electoral Systems and Their Political Consequences. Cambridge: Cambridge University Press, 190-208.

Clogg, Richard (1987). Parties and Elections in Greece: The Search for Legitimacy. Durham, NC: Duke University Press.

Dinas, Elias (2008). “The Greek General Election of 2007: You Cannot Lose if Your Opponent Cannot Win”, West European Politics, 31:3, 600-607.

Eleftheriadis, Pavlos (2005). "Constitutional Reform and the Rule of Law in Greece", West European Politics, 28:2, 317-34.

Featherstone, Kevin (1990). "The 'Party-State' in Greece and the Fall of Papandreou", West European Politics, 13:1, 101-15.

Foundethakis, Penelope (2003). "The Hellenic Parliament: The New Rules of the Game”, Journal of Legislative Studies, 9:2, 85-106.

Kalogirou, Aikaterini, and John Panaretos (1999). “Analysis and Comparison of Greek Parliamentary Electoral Systems of the Period 1974-1999”. Athens University of Economics and Business, Technical Report No. 72. Available at SSRN: http://ssrn.com/abstract=948365.

Kazamias, G., and D. Papadimitriou (2002). "The Elections in Greece, April 2000", Electoral Studies, 21:4, 649-55. 
Kovras, Iosif (2010). "The Parliamentary Election in Greece, October 2009", Electoral Studies 29:?,??-??

Limberes, Nickolas M. (1986). "The Greek Election of June 1985: A Socialist Entrenchment", West European Politics, 9:1, 142-47.

Lyrintzis, Christos (1984). "Political Parties in Post-Junta Greece: A Case of 'Bureaucratic Clientelism'?”, West European Politics, 7:2, 99-118.

Patrikios, Stratos, and Georgios Karyotis (2008). "The Greek Parliamentary Election of 2007”, Electoral Studies, 27:2 356-59.

Trantas, Georgios, Paraskevi Zagoriti, Torbjörn Bergman, Wolfgang C. Müller, and Kaare Strøm, “Greece: 'Rationalizing' Constitutional Powers in a Post-Dictatorial Country”, in Kaare Strøm, Wolfgang C. Müller, and Torbjörn Bergman (eds), Delegation and Accountability in Parliamentary Democracies. Oxford: Oxford University Press, 376-98.

Vegleris, Phaedo (1981). “Greek Electoral Law”, in Howard R. Penniman (ed.), Greece at the Polls: The National Elections of 1974 and 1977. Washington, D.C.: American Enterprise Institute for Public Policy Research, 21-48.

Verney, Susannah (1990). "Between Coalition and One-Party Government: The Greek Elections of November 1989 and April 1990”, West European Politics, 13:4, 1318. 


\section{Hungary}

Áder, János (1991). “Kinek az érdeke? A magyar választási rendszer jellemzése”, in Sándor Kurtán, Péter Sándor, and László Vass (eds.), Magyarország politikai évkönyve 1991. Budapest: Ökonómia Alapítvány, 68-74.

Benoit, Kenneth, and John W. Schiemann (2001). "Institutional Choice in New Democracies: Bargaining over Hungary's 1989 Electoral Law”, Journal of Theoretical Politics, 13:2, 153-82.

Bozóki, András, Márta Elbert, Melinda Kalmár, Béla Révész, Erzsébet Ripp, and Zoltán Ripp, eds. (1999/2000). A rendszerváltás forgatókönyve: Kerekasztal-tárgyalások 1989-ben. Eight volumes. Vol. 1-4: Budapest: Magvető, 1999; Vol 5-8: Budapest: Új Mandátum, 2000.

FIDESZ (1989 [1988]). “Programtervezet”, reprinted in Sándor Kurtán, Péter Sándor, and László Vass (eds.), Magyarország politikai évkönyve 1988. Budapest: RForma, 719-30.

Kalmár, Melinda, and Béla Révész (2000). “I/3. számú munkabizottság: A választásokkal kapcsolatos kérdések, a választójogi törvény: Bevezető”, in András Bozóki, Márta Elbert, Melinda Kalmár, Béla Révész, Erzsébet Ripp, and Zoltán Ripp (eds.), A rendszerváltás forgatókönyve: Kerekasztal-tárgyalások 1989-ben: Hatodik kötet: A nemzeti kerekasztal-tárgyalások politikai munkabizottságainak jegyzökönyvei. Budapest: Új Mandátum, 251-56.

Kosztricz, Anna S., ed. (1993). A Magyar Szocialista Munkáspárt Központi Bizottságának 1989. évi jegyzökönyvei. Two volumes. Budapest: Magyar Országos Levéltár. 
Lengyel, László (2000). “A kerekasztal hősei”, in András Bozóki, Márta Elbert, Melinda Kalmár, Béla Révész, Erzsébet Ripp, and Zoltán Ripp (eds.), A rendszerváltás forgatókönyve: Kerekasztal-tárgyalások 1989-ben: Hetedik kötet: Alkotmányos forradalom. Budapest: Új Mandátum, 203-18.

Renwick, Alan (2005). "Modelling Multiple Goals: Electoral System Preferences in Hungary in 1989”, Europe-Asia Studies, 57:7, 995-1019.

Schiemann, John W. (2001). "Hedging against Uncertainty: Regime Change and the Origins of Hungary's Mixed-Member System”, in Matthew Soberg Shugart and Martin P. Wattenberg, Mixed-Member Electoral Systems: The Best of Both Worlds? Oxford: Oxford University Press, 231-54.

SZDSZ (1990 [1989]). Untitled programme, reprinted in Sándor Kurtán, Péter Sándor, and László Vass (eds.), Magyarország politikai évkönyve 1990. Budapest: AulaOMIKK, 592-95.

Tölgyessy, Péter (1989). “Közjogi reformunk”, Világosság 30:7, 516-25.

\section{Iceland}

Hardarson, Ólafur Th. (2002). “The Icelandic Electoral System 1844-1999”, in Bernard Grofman and Arend Lijphart (eds.), The Evolution of Electoral and Party Systems in the Nordic Countries. New York: Agathon, 101-66.

Hardarson, Ólafur Thordur, and Gunnar Helgi Kristinsson (2008). “The Parliamentary Election in Iceland, May 2007”, Electoral Studies, 27:2, 373-7.

Kristinsson, Gunnar Helgi (1995). "The Icelandic Parliamentary Election of 1995", Electoral Studies, 14:3, 332-6. 
Kristjánsson, Svanur (2003). "Iceland: A Parliamentary Democracy with a SemiPresidential Constitution”, in Kaare Strøm, Wolfgang C. Müller, and Torbjörn Bergman (eds.), Delegation and Accountability in Parliamentary Democracies. Oxford: Oxford University Press, 399-417.

Kristjánsson, Svanur (2004). "Iceland: Searching for Democracy across Three Dimensions of Citizen Control”, Scandinavian Political Studies, 27:2, 153-74.

Kristjánsson, Svanur (2009). Personal communication.

Parliament of Iceland (2000). "Act Concerning Parliamentary Elections to the Althing, No. 24, 16 May". Available at http://eng.domsmalaraduneyti.is/laws-andregulations/nr/6713.

\section{Ireland}

Gallagher, Michael (2005). "Ireland: The Discreet Charm of PR-STV”, in Michael Gallagher and Paul Mitchell (eds.), The Politics of Electoral Systems. Oxford: Oxford University Press, 511-32.

O’Leary, Cornelius (1979). Irish Elections 1918-77: Parties, Voters and Proportional Representation. Dublin: Gill and Macmillan.

Ó Muineacháin, Séin, and Michael Gallagher (2008). “The Parliamentary Election in Ireland, May 2007”, Electoral Studies, 27:1, 151-4.

Sinnott, Richard (1999). "The Electoral System", in John Coakley and Michael Gallagher (eds.), Politics in the Republic of Ireland, 3rd edition. London: Routledge, in association with PSAI Press, 99-126. 
Italy

Atti Parliamentari (1954). "Seduta di Mercoledì 9 Giugno 1954”, Atti Parliamentari, Camera dei Deputati, Legislatura II, Discussioni, 8921-75.

Baldini, Gianfranco (2011). "Do All Roads Lead to Rome? The Different Trajectories of Italian Electoral Reform", West European Politics 34:?, ??-??.

Bull, Martin J., and James L. Newell (2005). Italian Politics: Adjustment under Duress. Cambridge: Polity Press.

Carstairs, Andrew McLaren (1980). A Short History of Electoral Systems in Western Europe. London: George Allen \& Unwin.

Donovan, Mark (1995). "The Politics of Electoral Reform in Italy", International Political Science Review, 16:1, 47-64.

Einaudi, Mario (1946). "Political Change in France and Italy", American Political Science Review, 40:5, 898-923.

Gambetta, Diego, and Steven Warner (1996). "The Rhetoric of Reform Revealed (or: If You Bite the Ballot May Bite Back)", Journal of Modern Italian Studies, 1:3, $357-76$

Gambetta, Diego, and Steven Warner (2004). "Italy: Lofty Ambitions and Unintended Consequences", in Josep M. Colomer (ed.), Handbook of Electoral System Choice. Basingstoke: Palgrave Macmillan, 237-52.

Gilbert, Mark (1995). The Italian Revolution: The End of Politics, Italian Style? Boulder, CO: Westview Press.

Grindrod, Muriel (1955). The Rebuilding of Italy: Politics and Economics, 1945-1955. London: Royal Institute of International Affairs. 
Katz, Richard S. (1996). "Electoral Reform and the Transformation of Party Politics in Italy", Party Politics, 2:1, 31-53.

Katz, Richard S. (2001). "Reforming the Italian Electoral Law, 1993", in Matthew Soberg Shugart and Martin P. Wattenberg (eds.), Mixed-Member Electoral Systems: The Best of Both Worlds? Oxford: Oxford University Press, 96-122.

Katz, Richard S, and Luciano Bardi (1980). "Preference Voting and Turnover in Italian Parliamentary Elections”, American Journal of Political Science, 24:1, 97-114.

Kogan, Norman (1966). A Political History of Postwar Italy. London: Pall Mall Press.

La Palombara, Joseph G. (1953). "The Italian Elections and the Problem of Representation”, American Political Science Review, 47:3, 676-703.

Massetti, Emanuele (2006). "Electoral Reform in Italy: From PR to Mixed System and (Almost) Back Again”, Representation, 42:3, 261-9.

Newell, James L., and Martin J. Bull (1993). “The Italian Referenda of April 1993: Real Change at Last?", West European Politics, 16:4, 607-15.

Pasquino, Gianfranco (1992). "The Electoral Reform Referendums”, in Robert Leonardi and Fausto Anderlini (eds.), Italian Politics: A Review, Volume 6. London: Pinter, 9-24.

Pasquino, Gianfranco (2007). “Tricks and Treats: The 2005 Italian Electoral Law and Its Consequences", South European Society \& Politics, 12:1, 79-93.

Piretti, Maria Serena (2003). La legge truffa. Il fallimento dell'ingegneria politica. Bologna: Il Mulino.

Pryce, Roy (1952). “The New Italian Electoral Law”, Parliamentary Affairs, 6:3, 26976. 
Pryce, Roy (1957). “The Italian General Election, 1958”, Parliamentary Affairs, 11:3, $318-27$.

Quagliariello, Gaetano (2003). La legge elettorale del 1953: dibattiti storici in Parlamento. Bologna: Il Mulino.

Renwick, Alan, Chris Hanretty, and David Hine (2009). "Partisan Self-Interest and Electoral Reform: The New Italian Electoral Law of 2005", Electoral Studies, $28: 3,437-47$.

Rich, Clifford A. L. (1953). "Political Trends in Italy", Western Political Quarterly, 6:3, $469-88$.

Seton-Watson, Christopher (1983). "Italy", in Vernon Bogdanor and David Butler (eds.), Democracy and Elections: Electoral Systems and their Political Consequences. Cambridge: Cambridge University Press, 110-21.

Smyth, Howard McGaw (1948). "Italy: From Fascism to the Republic", Western Political Quarterly 1:3, 205-22.

\section{Latvia}

Davies, Philip John, and Andrejs Valdis Ozolins (1996). “The Latvian Parliamentary Election of 1995", Electoral Studies, 15:1, 124-8.

Davies, Philip John, and Andrejs Valdis Ozolins (2001). “The 1998 Parliamentary Election in Latvia”, Electoral Studies, 20:1, 135-41.

Davies, Philip John, and Andrejs Valdis Ozolins (2004). "The Parliamentary Election in Latvia, October 2002”, Electoral Studies, 23:4, 834-40. 
Mikkel, Evald, and Vello Pettai (2004). "The Baltics: Independence with Divergent Electoral Systems", in Josep Colomer (ed.), Handbook of Electoral System Choice. Basingstoke: Palgrave Macmillan, 332-46.

Sprudzs, Adolf (2001). "Rebuilding Democracy in Latvia: Overcoming a Dual Legacy", in Jan Zielonka (ed.), Democratic Consolidation in Eastern Europe, Volume 1: Institutional Engineering. Oxford: Oxford University Press, 139-64.

\section{Lithuania}

Clark, Terry, and Žilvinas Martinaitis (2008). "Electoral Reform and Electoral System Effects in Lithuania”. Elections, Public Opinion, and Parties (EPOP) Conference, Manchester.

Clark, Terry, and Nerijus Prekivičius (2000). "The Effects of Changes to the Electoral Law in Premier-Presidential Systems: The Lithuanian Case”, Lithuanian Political Science Yearbook, 1, 112-25.

Clark, Terry D., and Nerijus Prekivičius (2003). "Explaining the 2000 Lithuanian Parliamentary Elections: An Application of Contextual and New Institutional Approaches", Slavic Review, 62:3, 548-69.

Gelazis, Nida (2001). "Institutional Engineering in Lithuania: Stability through Compromise", in Jan Zielonka (ed.), Democratic Consolidation in Eastern Europe, Volume 1: Institutional Engineering. Oxford: Oxford University Press, $165-85$.

Jurkynas, Mindaugas (2009a). "The Parliamentary Election in Lithuania, October 2008", Electoral Studies, 28:2, 329-33. 
Jurkynas, Mindaugas (2009b). Personal communication.

Krupavicius, A. (1997). “The Lithuanian Parliamentary Elections of 1996”, Electoral Studies, 16:4, 541-9.

Parliament of Lithuania (1996). "Law on the Amendment of the Law on Elections to the Seimas”, 27 June. Accessed at http://www3.lrs.lt/pls/inter3/dokpaieska.showdoc_e?p_id=31282\&p_query=\&p_tr 2=, 24 March 2010 .

Parliament of Lithuania (2008). "Seimo Rinkimu Istatymo". Accessed at http://www3.lrs.lt/pls/inter3/dokpaieska.showdoc_l?p_id=318823\&p_query=\&p_t r2=, 18 December 2009 .

Lukošaitis, Alvidas (2000). "The Context of Parliamentary Elections 2000: The Experience and Perspectives of Coalition Politics in Lithuania", Lithuanian Political Yearbook, 1, 139-66.

\section{Luxembourg}

Dumont, Patrick, and Lieven De Winter (2003). "Luxembourg: A Case of More "Direct" Delegation and Accountability", in Kaare Strøm, Wolfgang C. Müller, and Torbjörn Bergman (eds.), Delegation and Accountability in Parliamentary Democracies. Oxford: Oxford University Press, 474-97.

Inter-Parliamentary Union (n.d.). Parline Database. Available at www.ipu.org. 
Malta

Buhagiar, Anton, and Josef Lauri (2009). “STV in Malta: A Crisis?”, Voting Matters, 26, 1-12.

Fenech, Dominic (1992). “The 1992 Maltese Election”, West European Politics, 15:4, 189-95.

Fenech, Dominic (1997). “The 1996 Maltese Election: Swing of the Pendulum”, West European Politics, 20:2, 165-72.

Gonzi Commission [L. Gonzi, Austin Gatt, Paul Lia, Wenzu Mintoff, and J. R. Grima] (1994). Commission on the Electoral System: Final Report, trans. Joseph Felice Pace. Valetta. Available at Lane (n.d.).

Government of Malta (1990). "Reforming Malta's Electoral Laws" (White Paper). Valetta: Government of Malta. Available at Lane (n.d.).

Hirczy de Miño, Wolfgang, and John C. Lane (2000). "Malta: STV in a Two-Party System”, in Shaun Bowler, and Bernard Grofman (eds.), Elections in Australia, Ireland, and Malta under the Single Transferable Vote. Ann Arbor: University of Michigan Press, 178-204.

Howe, Stephen (1987). “The Maltese General Election of 1987”, Electoral Studies, 6:3 $235-47$.

Lane, John C. (n.d.). "Elections in Malta" (website). Available at www.maltadata.com.

Malta Independent. Articles archived at Lane (n.d.).

Malta Times. Articles archived at Lane (n.d.).

Malta Today. Available at www.maltatoday.com.mt. 
Zanella, Remo (1990). "The Maltese Electoral System and Its Distorting Effects", Electoral Studies, 9:3, 205-15.

\section{Netherlands}

Andeweg, Rudy B. (2005). "The Netherlands: The Sanctity of Proportionality", in Michael Gallagher and Paul Mitchell (eds.), The Politics of Electoral Systems. Oxford: Oxford University Press, 491-510.

Andeweg, Rudy B. (2009). Personal communication.

Andeweg, Rudy B., and Galen A. Irwin (2002). Governance and Politics of the Netherlands, 2nd edition. Basingstoke: Palgrave Macmillan.

Daalder, Hans (1955). "Parties and Politics in the Netherlands", Political Studies, 3:1, 116.

Daalder, Hans (1975). "Extreme Proportional Representation: The Dutch Experience”, in S. E. Finer (ed.), Adversary Politics and Electoral Reform. London: Anthony Wigram, 223-48.

Dutch Electoral System Civic Forum (2007). "Electoral System Civic Forum's Recommendations". Accessed at www.burgerforumkiesstelsel.nl, 9 August 2007. Dutch-language version submitted to Minister of Democratic Reform 14 December 2006.

Jacobs, Kristof (2010). Personal communication.

Jacobs, Kristof, and Monique Leyenaar (2011). "More than Meets the Eye: A Conceptual Framework for Major, Minor and Technical Electoral Reform", West European Politics, 34:?, ??-??. 
Keesing's Contemporary Archives (1952). 2-9 August, p. 12382, and 30 August - 6 September, p. 12430.

Keesing's Contemporary Archives (1956). 5-12 May, p. 14858.

Lijphart, Arend (1978). "The Dutch Electoral System in Comparative Perspective: Extreme Proportional Representation, Multipartism, and the Failure of Electoral Reform", Netherlands Journal of Sociology, 14:2, 115-33.

Parliament of the Netherlands (2008). “Act of 28 September 1989 Concerning New Provisions Governing the Franchise and Elections (Elections Act), Last Amended by Act of 25 September 2008”, Bulletin of Acts and Decrees, 405. Available at http://www.lexadin.nl/wlg/legis/nofr/eur/arch/ned/electionsact.pdf.

Van Raalte, E. (1959). The Parliament of the Kingdom of the Netherlands. London: The Hansard Society for Parliamentary Government.

Norway

Aardal, Bernt (1990). “The Norwegian Parliamentary Election of 1989”, Electoral Studies, 9:2, 151-8.

Aardal, Bernt (2002). "Electoral Systems in Norway", in Bernard Grofman and Arend Lijphart, eds. (2002), The Evolution of Electoral and Party Systems in the Nordic Countries. New York: Agathon, 167-224.

Arter, David (2006). Democracy in Scandinavia: Consensual, Majoritarian or Mixed? Manchester: Manchester University Press.

Heidar, Knut, and Jo Saglie (2001). "Predestined Parties? Organizational Change in Norwegian Political Parties”. ECPR Joint Sessions of Workshops, Grenoble. 
Narud, Hanne Marthe, and Kaare Strøm (2004). "Norway: Madisonianism Reborn", Scandinavian Political Studies, 27:2 175-201.

Parliament of Norway (2002). "Representation of the People Act (the Election Act) (Act No. 57 of 28 June 2002 Relating to Parliamentary and Local Government Elections". Available

at http://www.regjeringen.no/upload/KRD/Kampanjer/valgportal/Regelverk/Represe ntation_of_the_People_Act170609.pdf.

Rokkan, Stein (1970). "Electoral Systems", in Stein Rokkan, with Angus Campbell, Per Torsvik, and Henry Valen, Citizens, Elections, Parties: Approaches to the Comparative Study of the Processes of Development. Oslo: Universitetsforlaget, $147-68$.

Särlvik, Bo (1983). "Scandinavia", in Vernon Bogdanor, and David Butler (eds.), Democracy and Elections: Electoral Systems and Their Political Consequences. Cambridge: Cambridge University Press: 122-48.

Strøm, Kaare, and Jørn Y. Leipart (1993). "Policy, Institutions, and Coalition Avoidance: Norwegian Governments, 1945-1990”, American Political Science Review, 87:4, 870-87.

Strøm, Kaare, and Hanne Marthe Narud (2003). "Norway: Virtual Parliamentarism”, in Kaare Strøm, Wolfgang C. Müller, and Torbjörn Bergman (eds.), Delegation and Accountability in Parliamentary Democracies. Oxford: Oxford University Press, $523-51$.

Valen, Henry (1994). "List Alliances: An Experiment in Political Representation", in M. Kent Jennings, and Thomas E. Mann (eds.), Elections at Home and Abroad: 
Essays in Honor of Warren E. Miller. Ann Arbor: University of Michigan Press, $289-321$.

\section{Poland}

Benoit, Kenneth, and Jacqueline Hayden (2004). "Institutional Change and Persistence: The Evolution of Poland's Electoral System, 1989-2001”, Journal of Politics, $66: 2,396-427$.

Birch, Sarah, Frances Millard, Marina Popescu, and Kieran Williams (2002). Embodying Democracy: Electoral System Design in Post-Communist Europe. Basingstoke: Palgrave Macmillan, 25-47.

Chan, Kenneth Ka-Lok (2001). "Idealism versus Realism in Institutional Choice: Explaining Electoral Reform in Poland”, West European Politics, 24:3, 64-88.

Kaminski, Marek M. (2002). "Do Parties Benefit from Electoral Manipulation? Electoral Laws and Heresthetics in Poland, 1989-93", Journal of Theoretical Politics, 14:3, 325-58.

Millard, Frances (2003). "Elections in Poland 2001: Electoral Manipulation and Party Upheaval”, Communist and Post-Communist Studies, 36:1, 69-86.

Millard, Frances (2008). "Electoral-System Change in Poland". Elections, Public Opinion, and Parties (EPOP) Conference, Manchester.

Millard, Frances (2010). Personal communication.

Parliament of Poland (2001). "Ustawa z dnia 12 kwietnia 2001 r. - Ordynacja wyborcza do Sejmu Rzeczypospolitej Polskiej i do Senatu Rzeczypospolitej Polskiej”, as amended 2007. Available at 
http://www.pkw.gov.pl/pkw2/index.jsp?place=Menu01\&news_cat_id=21615\&la yout $=1$.

Parliament of Poland (2002). "Ustawa z dnia 26 lipca 2002 r. o zmianie ustawy Ordynacja wyborcza do rad gmin, rad powiatów i sejmików województw oraz o zmianie niektórych innych ustaw.” Dziennik Ustaw 10 sierpnia, nr. 127 poz. 1089.

\section{Portugal}

Freire, André, Manuel Meirinho, and Diogo Moreira (2009). "Institutional Reform in Portugal: Elite and Mass Perspectives". ECPR Joint Sessions of Workshops, Lisbon.

Gallagher, Tom (1983). Portugal: A Twentieth-Century Interpretation. Manchester: Manchester University Press.

Goldey, David B. (1983). "Elections and the Consolidation of Portuguese Democracy: 1974-1983”, Electoral Studies, 2:3, 229-40.

Inter-Parliamentary Union (n.d.). Parline Database. Available at www.ipu.org. Maxwell, Kenneth (1986). "Regime Overthrow and the Prospects for Democratic Transition in Portugal', in Guillermo O'Donnell, Philippe C. Schmitter, and Laurence Whitehead (eds.), Transitions from Authoritarian Rule: Southern Europe. Baltimore, MD: Johns Hopkins University Press, 109-37.

Maxwell, Kenneth (1995). The Making of Portuguese Democracy. Cambridge: Cambridge University Press. 
Pimlott, Ben (1977). "Parties and Voters in the Portuguese Revolution: The Elections of 1975 and 1976", Parliamentary Affairs, 30:1, 35-58.

Salgado, Susana (2007). "Parliamentary and Presidential Elections in Portugal, 2005 and 2006”, Electoral Studies, 26:2 512-16.

\section{Romania}

Birch, Sarah, Frances Millard, Marina Popescu, and Kieran Williams (2002). Embodying Democracy: Electoral System Design in Post-Communist Europe. Basingstoke: Palgrave Macmillan, 90-108.

Downs, William M. (2009). “The 2008 Parliamentary Election in Romania”, Electoral Studies, 28:3, 510-13.

Downs, William M. and Raluca V. Miller (2006). "The 2004 Presidential and Parliamentary Elections in Romania”, Electoral Studies, 25:2, 409-15.

Marian, Cosmin Gabriel, and Ronald F. King (2010). "Plus ça Change: Electoral Law Reform and the 2008 Romanian Parliamentary Elections", Communist and PostCommunist Studies, 43:1, 7-18.

Popescu, Marina (2002). “The Parliamentary and Presidential Elections in Romania, November 2000", Electoral Studies, 22:2, 325-35.

Popescu, Marina (2008). "Information, Interests and Ideas in Electoral System Reform: Romania in Comparative Perspective”. Elections, Public Opinion, and Parties (EPOP) Conference, Manchester.

Popescu, Marina (2009). Personal communication. 


\section{Slovakia}

Birch, Sarah, Frances Millard, Marina Popescu, and Kieran Williams (2002). Embodying Democracy: Electoral System Design in Post-Communist Europe. Basingstoke: Palgrave Macmillan, 75-9.

Bútora, Martin, Zora Bútorová, and Grigorij Mesežnikov (2003). “Slovakia’s Democratic Awakening”, in Jacque Rupnik and Jan Zielonka (eds), The Road to the European Union, Volume 1: The Czech and Slovak Republics. Manchester: Manchester University Press, 51-68.

European Commission (1997). “Agenda 2000 - Commission Opinion on Slovakia’s Application for Membership of the European Union”, DOC/97/20, 15 July. Brussels: $\quad$ European Available ammission. at http://ec.europa.eu/enlargement/archives/pdf/dwn/opinions/slovakia/sk-op_en.pdf. European Commission (1998). "Regular Report from the Commission on Slovakia's Progress towards Accession", 4 November. Brussels: European Commission. Available http://ec.europa.eu/enlargement/archives/pdf/key_documents/1998/slovakia_en.p df.

European Commission (1999). "1999 Regular Report from the Commission on Slovakia's Progress towards Accession", 13 October. Brussels: European Commission. Available at http://ec.europa.eu/enlargement/archives/pdf/key_documents/1999/slovakia_en.p df. 
European Commission (2000). "2000 Regular Report from the Commission on Slovakia's Progress towards Accession”, 8 November. Brussels: European Commission. Available at http://ec.europa.eu/enlargement/archives/pdf/key_documents/2000/sk_en.pdf.

Fitzmaurice, John (1999). "The Slovak Elections of 25th and 26th September 1998", Electoral Studies, 18:2, 291-5.

Fitzmaurice, John (2004). "The Parliamentary Election in Slovakia, September 2002", Electoral Studies, 23:1, 160-66.

Kopecký, Petr (2001). Parliaments in the Czech and Slovak Republics: Party Competition and Parliamentary Institutionalization. Aldershot: Ashgate.

Malová, Darina (2001). "Slovakia: From the Ambiguous Constitution to the Dominance of Informal Rules", in Jan Zielonka (ed.), Democratic Consolidation in Eastern Europe, Volume 1: Institutional Engineering. Oxford: Oxford University Press, $347-77$.

Parliament of Slovakia (1998). "Act No. 80/1990 of the Slovak National Council on Elections to the Slovak National Council", as amended 1998. Available at www.legislationline.org.

Parliament of Slovakia (2004). "Act No. 333 in the Collection of Laws of 13 May 2004 on Elections to the National Council of the Slovak Republic". Available at www.legislationline.org.

Pridham, Geoffrey (2002). “The European Union's Democratic Conditionality and Domestic Politics in Slovakia: The Mečiar and Dzurinda Governments Compared", Europe-Asia Studies, 54:2, 203-27. 
Pridham, Geoffrey (2005). Designing Democracy: EU Enlargement and Regime Change in Post-Communist Europe. Basingstoke: Palgrave Macmillan.

Rybáŕ, Marek (2007). “The Parliamentary Election in Slovakia, June 2006”, Electoral Studies, 26:3, 699-703.

\section{Slovenia}

Fink-Hafner, Danica (2008). "Much Ado about Nothing: Electoral Reform in Slovenia". Elections, Public Opinion, and Parties (EPOP) Conference, Manchester. Matic, Andrej Auersperger (2000). "Electoral Reform as a Constitutional Dilemma", East European Constitutional Review, 9:3, 77-81.

Parliament of Slovenia (2000). "National Assembly Elections Act" (1992, as amended 2000). Available at www.legislationline.org.

Toplak, Jurij (2006). “The Parliamentary Election in Slovenia, October 2004”, Electoral Studies, 25:4, 825-31.

Toplak, Jurij (2009). Personal communication.

Spain

Capo Giol, Jordi (1990). “To Reform the Electoral System in Spain?", in Serge Noiret (ed.), Political Strategies and Electoral Reforms: Origins of Voting Systems in Europe in the 19th and 20th Centuries. Baden-Baden: Nomos Verlagsgesellschaft, 403-22. 
Colomer, Josep M. (2004). “Spain: From Civil War to Proportional Representation”, in Josep Colomer (ed.), Handbook of Electoral System Choice. Basingstoke: Palgrave Macmillan, 253-64.

Coverdale, John F. (1979). The Political Transformation of Spain after Franco. New York: Praeger.

De Esteban, Jorge, and Luis López Guerra (1985). "Electoral Rules and Candidate Selection", in Howard R. Penniman and Eusebio M. Mujal-León (eds.), Spain at the Polls, 1977, 1979, and 1982: A Study of the National Elections. Durham, NC: Duke University Press, 48-72.

Field, Bonnie N. (2009). “The Parliamentary Election in Spain, March 2008”. Electoral Studies, 28:1, 155-8.

Field, Bonnie N., and Kerstin Hamann (2008). "Conclusion: The Spanish Case and Comparative Lessons on Institutions, Representation, and Democracy", in Bonnie N. Field and Kerstin Hamann (eds.), Democracy and Institutional Development: Spain in Comparative Theoretical Perspective. Basingstoke: Palgrave Macmillan, 203-16.

Gilmour, David (1985). The Transformation of Spain: From Franco to the Constitutional Monarchy. London: Quartet Books.

Gunther, Richard, Giacomo Sani, and Goldie Shabad (1986). Spain after Franco: The Making of a Competitive Party System. Berkeley, CA: University of California Press. 
Hopkin, Jonathan (2005). "Spain: Proportional Representation with Majoritarian Outcomes", in Michael Gallagher and Paul Mitchell (eds.), The Politics of Electoral Systems. Oxford: Oxford University Press, 375-94.

Maravall, José María, and Julián Santamaría (1986). "Political Change in Spain and the Prospects for Democracy”, in Guillermo O’Donnell, Philippe C. Schmitter, and Laurence Whitehead (eds.), Transitions from Authoritarian Rule: Southern Europe. Baltimore: Johns Hopkins University Press, 71-108.

Medhurst, Kenneth N. (1973). Government in Spain. Oxford: Pergamon Press.

Meisler, Stanley (1977). “Spain’s New Democracy”, Foreign Affairs, 56:1, 190-208.

Montero, José Ramón, and Ignacio Lago (2007). “The Selection of an Electoral System: Less Consensus, More Heresthetics". ECPR General Conference, Pisa.

Payne, Stanley (1985). "Representative Government in Spain: The Historical Background”, in Howard R. Penniman and Eusebio M. Mujal-León (eds.), Spain at the Polls, 1977, 1979, and 1982: A Study of the National Elections. Durham, NC: Duke University Press, 1-29.

Vallés, Josep M. (1986). "Sistema electoral y democracia representativa: Nota sobre la Ley Orgánica del Régimen Electoral General de 1985 y su función política”, Revista de Estudios Políticos 53 (new series): 7-28.

Varela Ortega, José, and Rogelio A. Lopez Blanco (1990). "Historiography, Sources and Methods for the Study of Electoral Laws in Spain”, in Serge Noiret, ed. Political Strategies and Electoral Reforms: Origins of Voting Systems in Europe in the 19th and 20th Centuries. Baden-Baden: Nomos Verlagsgesellschaft, 185-259. 
Sweden

Arter, David (2006). Democracy in Scandinavia: Consensual, Majoritarian or Mixed? Manchester: Manchester University Press.

Bergman, Torbjörn (2003). "Sweden: From Separation of Power to Parliamentary Supremacy - and Back Again?”, in Kaare Strøm, Wolfgang C. Müller, and Torbjörn Bergman (eds.), Delegation and Accountability in Parliamentary Democracies. Oxford: Oxford University Press, 594-619.

Bergman, Torbjörn (2004). "Sweden: Democratic Reforms and Partisan Decline in an Emerging Separation-of-Powers System”, Scandinavian Political Studies, 27:2, $203-25$.

Congleton, Roger D. (2003). Improving Democracy through Constitutional Reform: Some Swedish Lessons. Boston: Kluwer.

Forsell, Harry (1971). “The Elections in Sweden in September 1970: Politics in a MultiLevel Election”, Scandinavian Political Studies, 6 (old series): 201-11.

Hancock, M. Donald (1972). Sweden: The Politics of Postindustrial Change. London: The Dryden Press.

Immergut, Ellen M. (2002). "The Swedish Constitution and Social Democratic Power: Measuring the Mechanical Effect of a Political Institution", Scandinavian Political Studies, 25:3, 231-57.

Lewin, Leif (1998). "Majoritarian and Consensus Democracy: The Swedish Experience”, Scandinavian Political Studies, 21:3, 195-206.

Möller, Tommy (1999). “The Swedish Election 1998: A Protest Vote and the Birth of a New Political Landscape", Scandinavian Political Studies, 22:3, 261-76. 
Rokkan, Stein (1970). "Electoral Systems", in Stein Rokkan, with Angus Campbell, Per Torsvik, and Henry Valen, Citizens, Elections, Parties: Approaches to the Comparative Study of the Processes of Development. Oslo: Universitetsforlaget, $147-68$.

Ruin, Olof (1988). "Sweden: The New Constitution (1974) and the Tradition of Consensual Politics", in Vernon Bogdanor, ed. Constitutions in Democratic Politics. Aldershot: Gower, 309-27.

Rustow, Dankwart A. (1969 [1955]). The Politics of Compromise: A Study of Parties and Cabinet Government in Sweden. New York: Greenwood Press. First published by Princeton University Press, 1955.

Särlvik, Bo (1983). "Scandinavia", in Vernon Bogdanor, and David Butler (eds.), Democracy and Elections: Electoral Systems and Their Political Consequences. Cambridge: Cambridge University Press: 122-48.

Särlvik, Bo (2002). "Party and Electoral System in Sweden", in Bernard Grofman and Arend Lijphart (eds.), The Evolution of Electoral and Party Systems in the Nordic Countries. New York: Agathon, 225-69.

\section{Switzerland}

Dardanelli, Paolo (2008). “The Swiss Federal Elections of 2007”, Electoral Studies, $27: 4,748-51$.

Lutz, Georg (2004). "Switzerland: Introducing Proportional Representation from Below", in Josep M. Colomer (ed.), Handbook of Electoral System Choice. Basingstoke: Palgrave Macmillan, 279-93. 


\section{United Kingdom}

Butler, D. E. (1963). The Electoral System in Britain since 1918, 2nd edition. Oxford: Oxford University Press.

Farrell, David M. (2001). "The United Kingdom Comes of Age: The British Electoral Reform "Revolution" of the 1990s", in Matthew Soberg Shugart and Martin P. Wattenberg (eds.), Mixed-Member Electoral Systems: The Best of Both Worlds? Oxford: Oxford University Press, 521-41. 